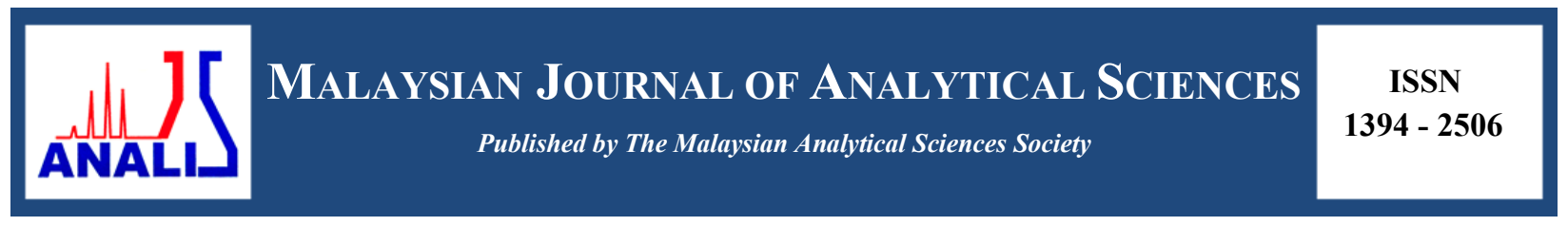

\title{
SYNTHESIS AND CHARACTERIZATION OF EPOXIDIZED NEOPENTHYL GLYCOL DIOLETE AS AN INTERMIDIATE OF BIOLUBRICANT
}

\section{(Sintesis dan Pencirian Epoksida Dioleat Neopentil Glikol Sebagai Bahan Perantara Biopelincir)}

\author{
Vanitah Rajaendran ${ }^{1}$, Jumat Salimon ${ }^{1}$, Rahimi M.Yusop ${ }^{1,2 *}$ \\ ${ }^{I}$ School of Chemical Sciences and Food Technology, Faculty of Science and Technology, \\ Universiti Kebangsaan Malaysia, 43600 UKM Bangi, Selangor, Malaysia \\ ${ }^{2}$ Regenerative Medicine Cluster, Advance Medical and Dental Institute, \\ Universiti Sains Malaysia, 13200 Bertam Kepala Batas, Pulau Pinang, Malaysia
}

*Corresponding author: rahimi@ukm.edu.my

Received: 4 April 2016; Accepted: 5 August 2016

\begin{abstract}
Neopenthyl glycol dioleate (NPGDO) is a biolubricant base that was formed via esterification process with oleic acid. The presence of oleic acid leads to poor oxidative stability. In this study, epoxidation reaction between NPGDO, formic acid and hydrogen peroxide has been carried out to produce epoxidized NPG dioleate (ENPGDO) which acts as the intermediate of biolubricant. Epoxidized oil can be further modified for better properties. The temperature for this reaction was $40{ }^{\circ} \mathrm{C}$ and the molar ratio of NPGDO:formic acid:hydrogen peroxide was 1:3:4. The reaction had taken place for 3 hours. The presence of the epoxy in the product was confirmed through Fourier Transform Infrared (FTIR). The structure of ENPGDO was confirmed using both proton and carbon Nuclear Magnetic Resonance $\left({ }^{1} \mathrm{H}-\mathrm{NMR}\right.$ and $\left.{ }^{13} \mathrm{C}-\mathrm{NMR}\right)$ analysis. The product was found to have 218 (viscosity indeks), $205^{\circ} \mathrm{C}$ (flash point), $-18{ }^{\circ} \mathrm{C}$ (pour point) and $197{ }^{\circ} \mathrm{C}$ (oxidative stability). The relative conversion of oxirane (RCO) for ENPGDO was $97.5 \%$.
\end{abstract}

Keywords: biolubricant, neopenthyl glycol, oleic acid, epoxidized NPG diolete

\begin{abstract}
Abstrak
Dioleat neopentil glikol (DONPG) merupakan bahan asas biopelincir yang dihasilkan melalui tindak balas pengesteran dengan asid oleik. Kehadiran asid oleik menjadikan kestabilan oksidatifnya rendah. Di dalam penyelidikan ini, pengepoksidaan antara DONPG, asid formik dan hidrogen peroksida dilakukan bagi menghasilkan epoksida dioleat NPG (EDONPG) yang bertindak sebagai bahan perantara biopelincir. Modifikasi kimia dilakukan ke atas EDONPG menghasilkan sifat yang lebih baik. Suhu bagi tindak balas ini adalah $40^{\circ} \mathrm{C}$ dan nisbah molar DONPG: asid formik: hidrogen peroksida adalah 1:3:4. Masa tindak balas adalah 3 jam. Kehadiran epoksi di dalam produk ditentukan melalui spektroskopi Fourier transformasi inframerah (FTIR). Struktur EDONPG pula ditentukan melalui proton dan karbon spektroskopi resonan magnetik nuklear $\left({ }^{1} \mathrm{H}-\mathrm{NMR}\right.$ and $\left.{ }^{13} \mathrm{C}-\mathrm{NMR}\right)$. Pencirian fizikal produk dimana indeks kelikatan produk adalah $(218)$, takat kilat $\left(205^{\circ} \mathrm{C}\right)$, takat tuang $\left(-18{ }^{\circ} \mathrm{C}\right)$ dan kestabilan oksidatif $\left(197^{\circ} \mathrm{C}\right)$. Relatif pertukaran oksirana (RCO) produk ialah $97.5 \%$.
\end{abstract}

Kata kunci: biopelincir, neopentil glikol, asid oleik, epoksida dioleat NPG

\section{Introduction}

Biolubricant is a perfect substitute of mineral-based lubricants. The utilization of renewable feedstock to produce biolubricants has overcome the depletion of source problem faced by mineral-based lubricants. The biodegradable feedstock reduces environment pollution issues [1]. Biolubricants also have high viscosity index, high flash points, 
good lubricity and less toxic properties. Hence, the subject of biolubricant has become the key interest by researchers and highly favourable by consumers. Although, biolubricants may have poor low temperature properties, as well as low oxidative and thermal stability [2] which require improvements through chemical modifications such as epoxidation and oxirane ring opening.

The highly reactive epoxide is a three-membered cyclic ether that suits the characteristic of an excellent raw material for further chemical modification. This chemical modification such as oxirane ring opening could improvise the properties of a product to make it more practical for industrial uses [3]. Epoxide products have extensively been used as a plasticizer and additive in biolubricant [4]. It is rather crucial for biolubricants to have a good oxidative stability as it reflects the quality and shelf life of the oil. Therefore, epoxidation could be performed to produce oil with better oxidative stability.

Recently, a growing body of literature has established the relavence of vegetable oil or unsaturated fatty acids epoxidation. The epoxidized carbon double bond provides a space for further reactions. Epoxidation on mustard oil was carried out which resulted in better oxidative sability [5]. The improvement on oxidative stability was achieved by converting the double bond in oil into oxirane ring. Epoxidation process can be carried out with and without the presence of catalyst. A catayst is used to produce higher yield and percentage of RCO.

In this study, the main purpose was to develop a biolubricant intermediate from NPGDO via epoxidation. Epoxidation was conducted without catalyst. Optimization of epoxidation was carried out to produce ENPGDO with higher yield and maximum percentage of RCO at mild condition. Epoxidized NPGDO act as an intermediate of biolubricant.

\section{Materials}

\section{Materials and Methods}

The NPGDO used was synthesized in the laboratory. It was prepared via esterification between NPG and oleic acid in ratio $1: 2$ at $130{ }^{\circ} \mathrm{C}$ for 4 hours with $2 \%$ of sulphuric acid as a catalyst. The NPGDO was purified. Hydrogen peroxide, formic acid and sodium chloride used in this experiment were purchased from Systerm. The sodium hydrogen bicarbonate and sodium sulphate were purchased from R\&M Chemicals.

\section{Epoxidation procedure}

The NPGDO was added into a $250 \mathrm{ml}$ three-necked round bottom flask which was equipped with thermometer, magnetic stirer and a stopper. Formic acid was added according to mole ratio ranging from 1:1 up to 1:5 of NPGDO:formic acid. The round bottom flask was attached to a condenser with heating mantle. Temperature and reaction time were tested at $20{ }^{\circ} \mathrm{C}$ to $60{ }^{\circ} \mathrm{C}$ and 2 hours up to 6 hours respectively. Peroxide acid was then added drop wise into the flask for 60 minutes. Mole ratio of NPGDO to peroxide acid used in this experiment was $1: 1$ to 1:5. At the end of the reaction, the mixture was washed with $100 \mathrm{~mL}$ of $5 \%$ of sodium bicarbonate, $100 \mathrm{~mL}$ of $5 \%$ sodium chloride and $100 \mathrm{~mL}$ of distilled water to remove the acidity. It was then dried overnight with magnesium sulphate. The ethyl acetate solvent used in the mixture to extract oil was removed using a rotary evaporator [6].

\section{Epoxidized NPG dioleate analysis}

The oxirane oxygen content $(\% \mathrm{OOC})$ were calculated according to AOCS recommended practices. The relative conversion to oxirane was calculated using the following expression (equation 1) as reported by Michelle [3]:

Relative conversion to oxirane content:

$$
\mathrm{RCO}=O O c / O O t
$$

where, $O O c$ is define as experimental oxygen oxirane and $O O t$ is define as theoretical maximum oxirane oxygen from the expression (equation 2);

$$
O O_{\mathrm{t}}=\left(\frac{I V_{\mathrm{O}} / 2 A i}{100+\left(I V_{\mathrm{O}} / 2 A i\right) A_{\mathrm{O}}}\right) A o \times 100
$$


where, $A_{i}(126.9)$ and $A_{0}(16)$ are atomic weight of iodine and oxygen respectively. Meanwhile, $I V_{0}$ is the initial iodine value of sample.

Formation of epoxy was confirmed by using Perkin Elmer GX FTIR in the range of $400 \mathrm{~cm}^{-1}$ to $4000 \mathrm{~cm}^{-1}$. Subsequently, the ENPGDO was analysed with ${ }^{1} \mathrm{H}$ NMR and ${ }^{13} \mathrm{C}$ NMR using Bruker ARX-600 for structure conformation. Tetramethyl Silen (TMS) were used as internal standard with deuterochloroform as solvent.

\section{Epoxidized NPG dioleate physicochemical analysis}

The improvement in the characteristics of NPGDO and ENPGDO were analysed. For the pour point and oxidative stability, Differential Scanning Calorimetri (DSC) was used. The flash point was determined using ASTM D92 method (ASTM1965). The viscosity of the sample was analysed using Rhemometer Anton Paar at $40{ }^{\circ} \mathrm{C}$ and $100{ }^{\circ} \mathrm{C}$. For the calculation of viscosity index (VI), ASTM 2270 method (ASTM 1964), the equation 3 or 4 was used as below:

For oils of 0 to $100 \mathrm{VI}$ :

$$
\mathrm{VI}=[(\mathrm{L}-\mathrm{U}) /(\mathrm{L}-\mathrm{H})] \times 100
$$

where, $\mathrm{U}$ is define as kinematic viscocity of oil in centistokes at $40{ }^{\circ} \mathrm{C}, \mathrm{L}$ and $\mathrm{H}$ is value from Table $\mathrm{L}$ and $\mathrm{H}$ based on kinematic viscocity $(\mathrm{cSt})$ at $100^{\circ} \mathrm{C}$.

For oils of $100 \mathrm{VI}$ and greater:

$$
\mathrm{VI}=[((\operatorname{antilog} \mathrm{N})-1) / 0.00715]=100
$$

where, $\mathrm{U}$ is define as kinematic viscocity of oil in centistokes at $40{ }^{\circ} \mathrm{C}, \mathrm{Y}$ is define as kinematic viscocity of oil in centistokes at $100^{\circ} \mathrm{C}$, and $\mathrm{L}$ and $\mathrm{H}$ is the value from Table $\mathrm{L}$ and $\mathrm{H}$ based on kinematic viscocity (cSt) at $100^{\circ} \mathrm{C}$.

\section{Results and Discussion}

Neopentyl glycol (NPG) is a polyhydic alcohol. It does not contain hydrogen in $\beta$ position as glycerol. $\beta$ hydrogen atom can lead to partial defragmentation into unsaturated compound at high temperature. This compound will later undergo polymerization and form precipitates [7]. In this study, NPG was esterified with oleic acid to form NPGDO. Unsaturation leads to poor oxidative and thermal stability. Meanwhile saturated fatty acid will cause poor low temperature properties. Monounsaturated oleic acid gives moderate oxidative stability and better low temperature properties. It also provides space for chemical modification to improve the properties of NPGDO [7].

Epoxidation of olefin is an important reaction for further chemical modification on NPGDO. The double bond of oleic acid in NPGDO causes the poor oxidative stability. The oxidative and thermal stability have been improved via epoxidation. Epoxidized oil acts as antirust in biolubricant. The biodegradability of oil remains the same [8]. Figure 1 shows the reaction scheme of epoxidized NPG dioleat. Epoxide is a compound with a cyclic ether with three-ring atom which is highly strained. Due to this, it is very reactive and treated as an intermediate for further reaction [3].

The optimization for this reaction was done to obtain ENPGDO in high yield with high oxygen oxirane content (OOC) and high percentage of RCO. OOC value describes the weight percent of oxirane oxygen in a molecule. It shows the conversion of unsaturation to epoxy groups [9]. Figure 2 shows the effect of different mol ratio of NPGDO:formic acid on percentage of RCO. From Figure 2, the highest percentage of RCO is at mol ratio 1:3. 

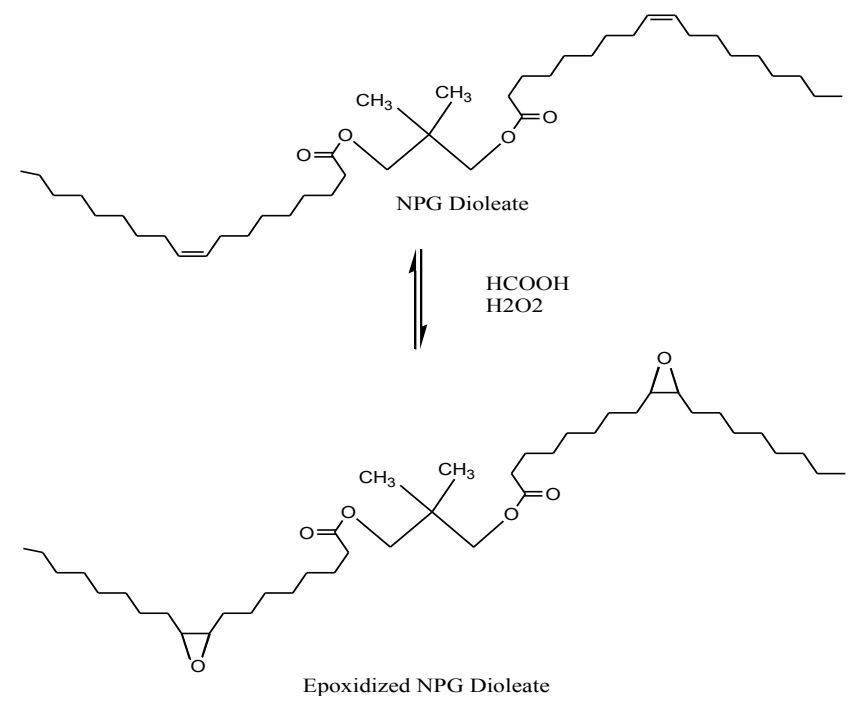

Figure 1. Reaction scheme for the epoxidized NPG dioleate

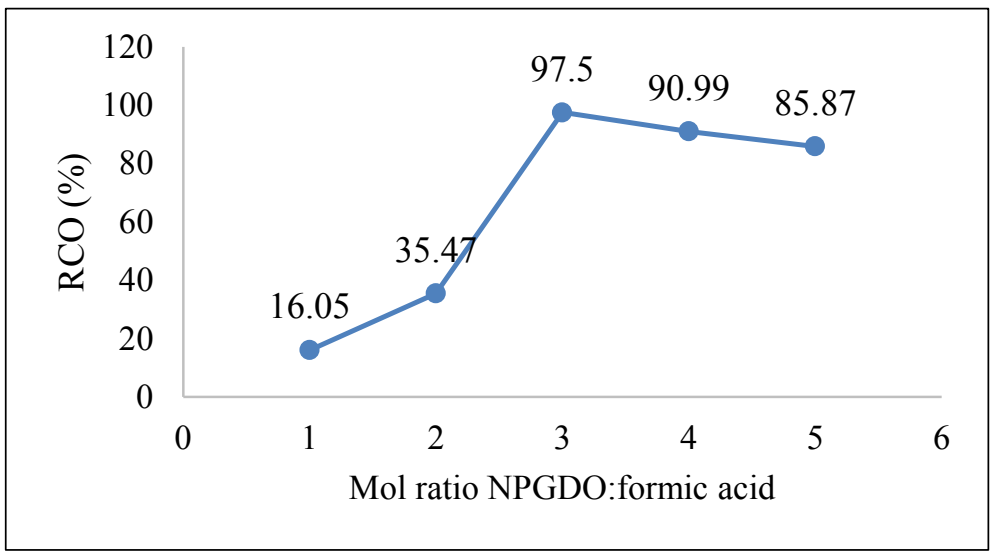

Figure 2. Effect of mol ratio NPGDO:formic acid on percentage of RCO

Figure 3 shows the percentage of RCO in accordance to mol ratio of NPGDO:hydrogen peroxide. The highest percentage of RCO can be seen at mol ratio 1:4. Figure 4 shows the effect of temperature towards the percentage of RCO. At $40{ }^{\circ} \mathrm{C}$, highest percentage of RCO was obtained. Figure 5 shows the correlation between time of rection on percentage of RCO which remarks $97 \%$ as the highest percentage of RCO, obtained after 3 hours of reaction. 


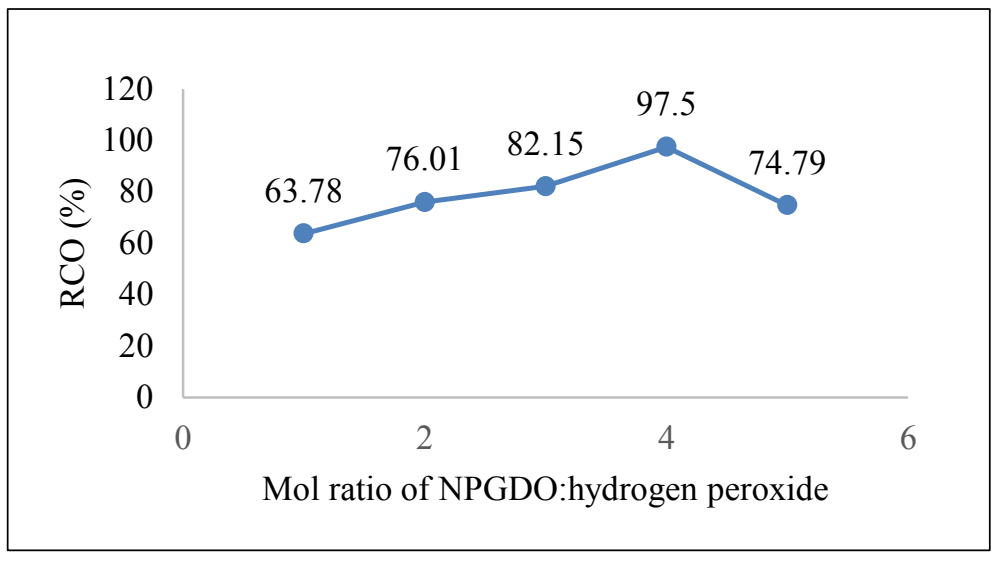

Figure 3. Effect of mol ratio NPGDO: hydrogen peroxide on percentage of RCO

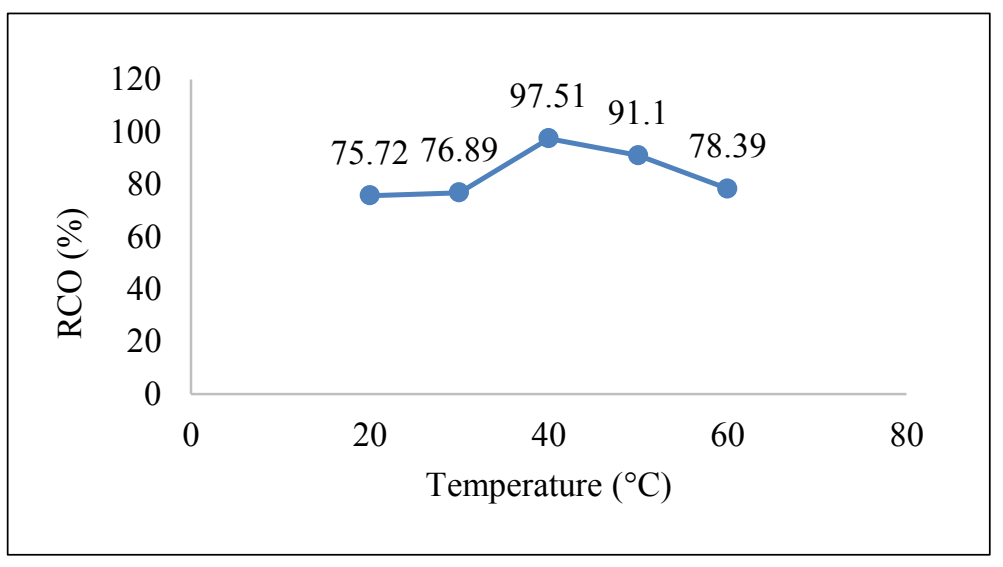

Figure 4. Effect of temperature on percentage of RCO

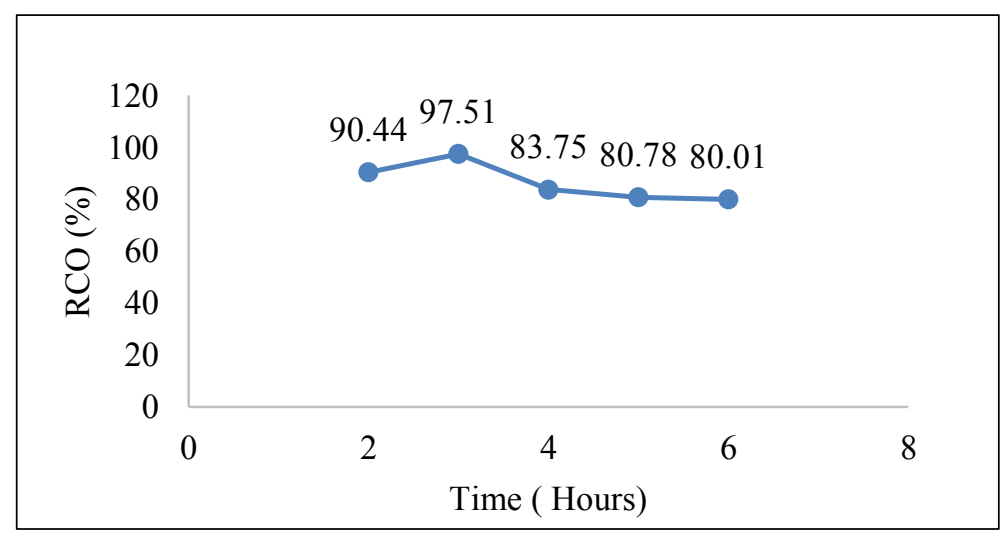

Figure 5. Effect of time of reaction on percentage of RCO 
From the optimization graph, it can be concluded that the best condition for the formation of ENPGDO was obtained at $40{ }^{\circ} \mathrm{C}$ for 3 hours. The mol ratio of NPGDO:formic acid:hydrogen peroxide was 1:3:4. The yield obtained was at average $83 \%$. The percentage of OOC was high at $4.3 \%$ and the percentage of conversion of double bond in NPG dioelate to epoxy ring was 97\%. The formation of ENPGDO was confirmed with Fourier Transform Infrared (FTIR) analysis. Figure 6 shows the comparison of FTIR spectrum before and after epoxidation of NPGDO. Peaks at $821.25 \mathrm{~cm}^{-1}$ and $933.33 \mathrm{~cm}^{-1}$ represent the $\mathrm{C}-\mathrm{O}-\mathrm{C}$ stretching of epoxide. There is no peak in the range of $3000 \mathrm{~cm}^{-1}$ to $3100 \mathrm{~cm}^{-1}$ which indicates that all the double bond in NPGDO has been converted into epoxide. The $\mathrm{O}-\mathrm{H}$ stretching band that should have been appeared between $3200 \mathrm{~cm}^{-1}$ to $3400 \mathrm{~cm}^{-1}$ is also absent. This proves that ring opening did not occur.

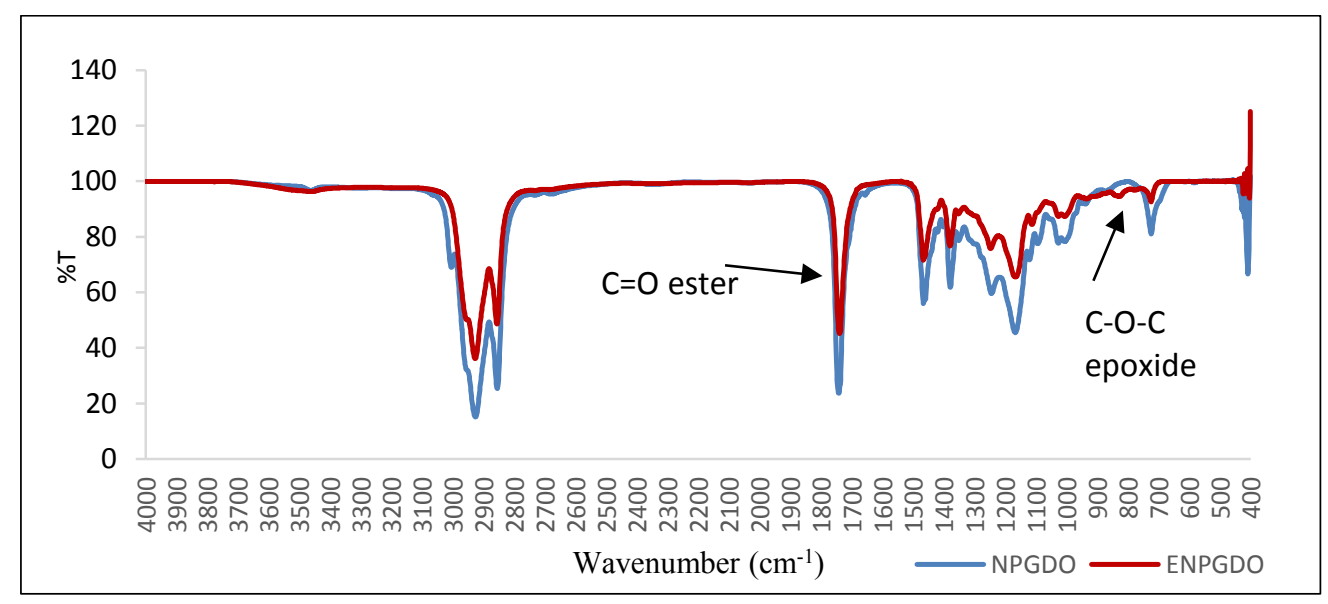

Figure 6. Comparison of FTIR spectrum between NPGDO and ENPGDO

The structural conformation was validated with Nuclear Magnetic Resonance (NMR). Figure 7 shows the ${ }^{1} \mathrm{H}$ NMR spectra.

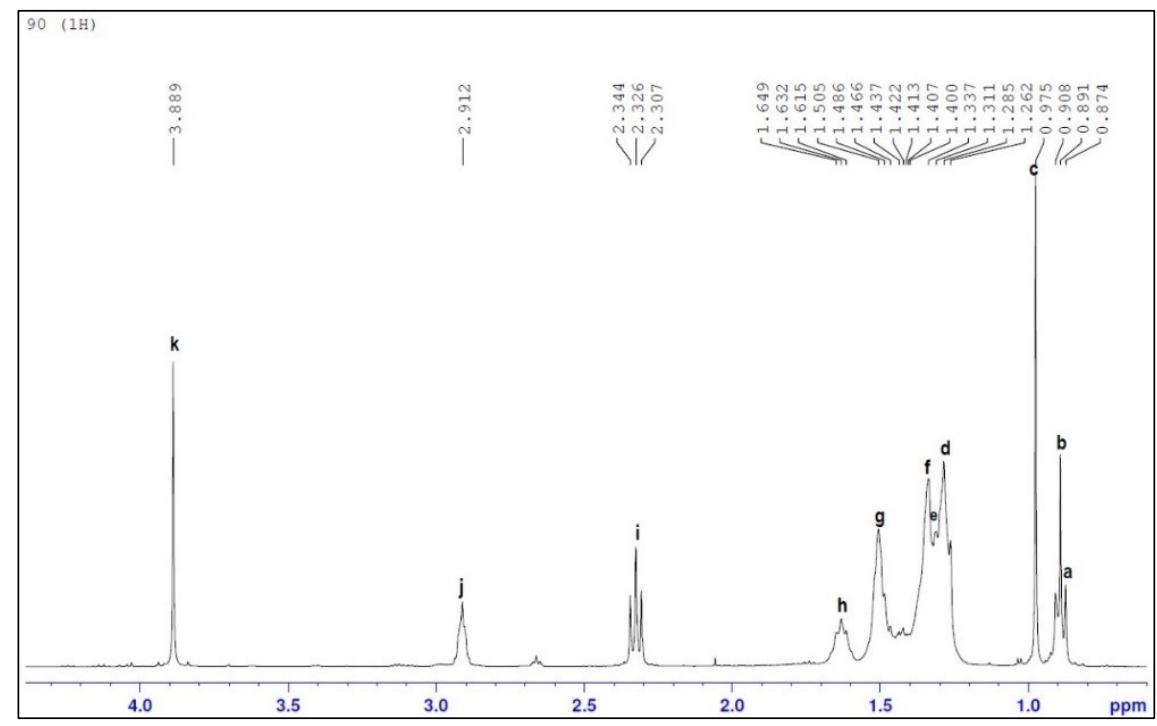

Figure 7. ${ }^{1} \mathrm{H}$ NMR spectra for epoxidized NPG dioleate 
Label on Figure 8 represents respective signals on ${ }^{1} \mathrm{H}$ NMR spectra. The peak at $2.9 \mathrm{ppm}$ corresponds the the proton attached to the epoxide group. The absence of peak at $5.381 \mathrm{ppm}$ proves that all double bond has been converted to epoxides. Figure 9 shows the ${ }^{13} \mathrm{C}$ NMR spectra and label on Figure 10 represents respective signals on the ${ }^{13} \mathrm{C}$ NMR spectra. The absence of peak at $120 \mathrm{ppm}$ to $140 \mathrm{ppm}$ prove the absence of double bond in the product. Meanwhile the peak at chemical shift $57 \mathrm{ppm}$ proves the formation of epoxide in the product.

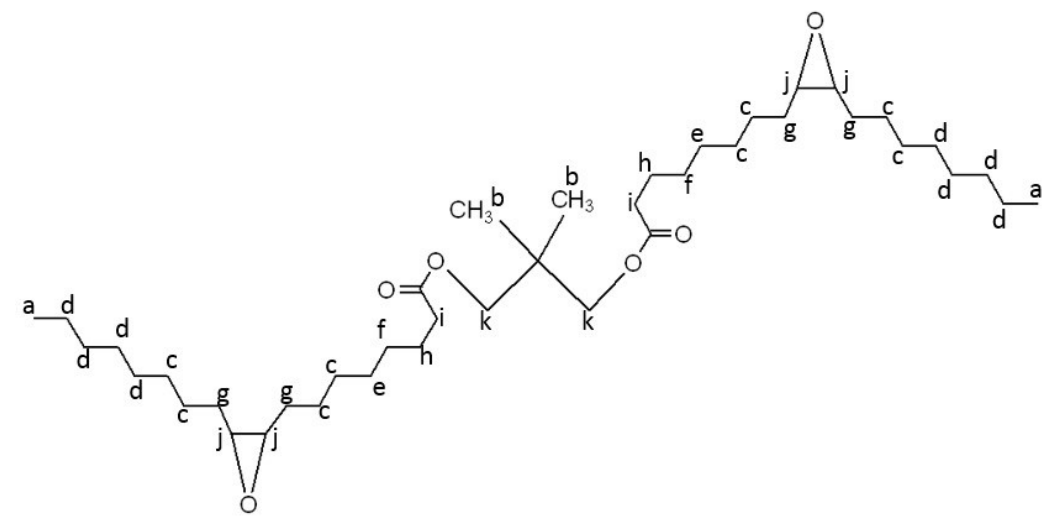

Figure 8. Structure representing signals on ${ }^{1} \mathrm{H}$ NMR spectra

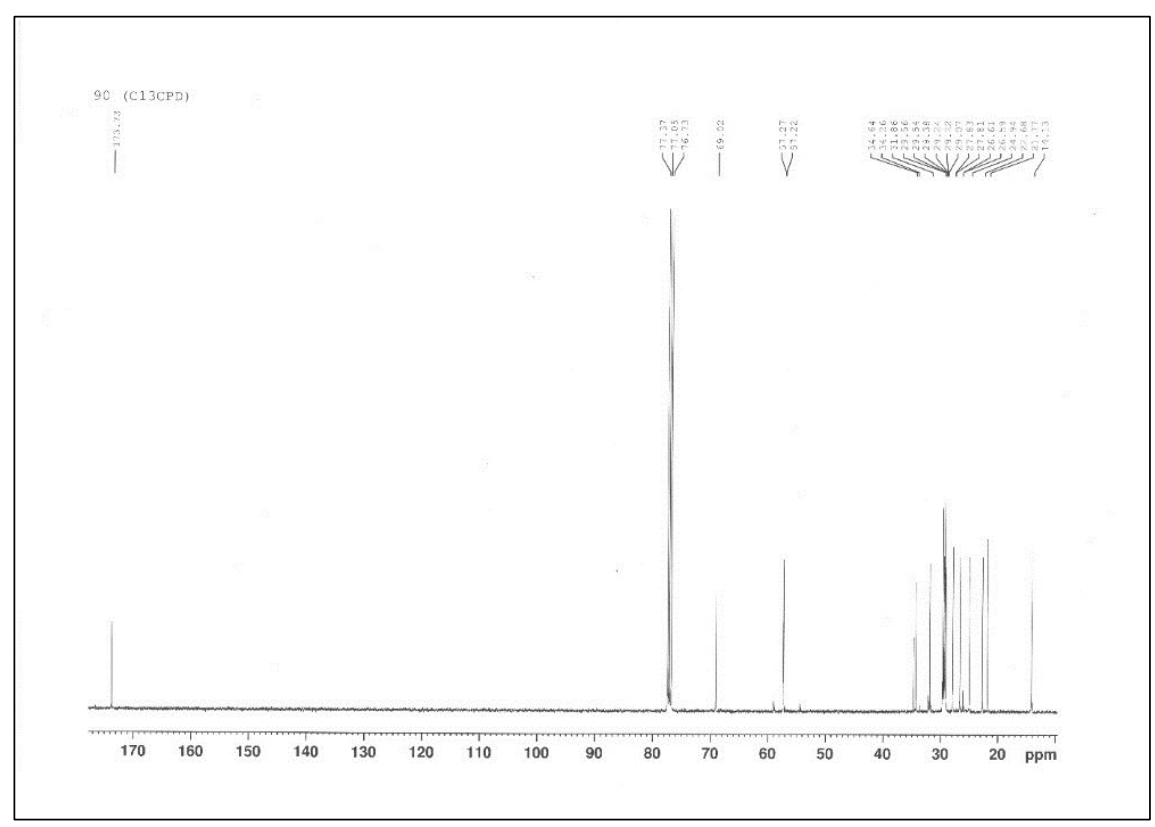

Figure 9. ${ }^{13} \mathrm{C}$ NMR Spectra for epoxidized NPG dioleate 


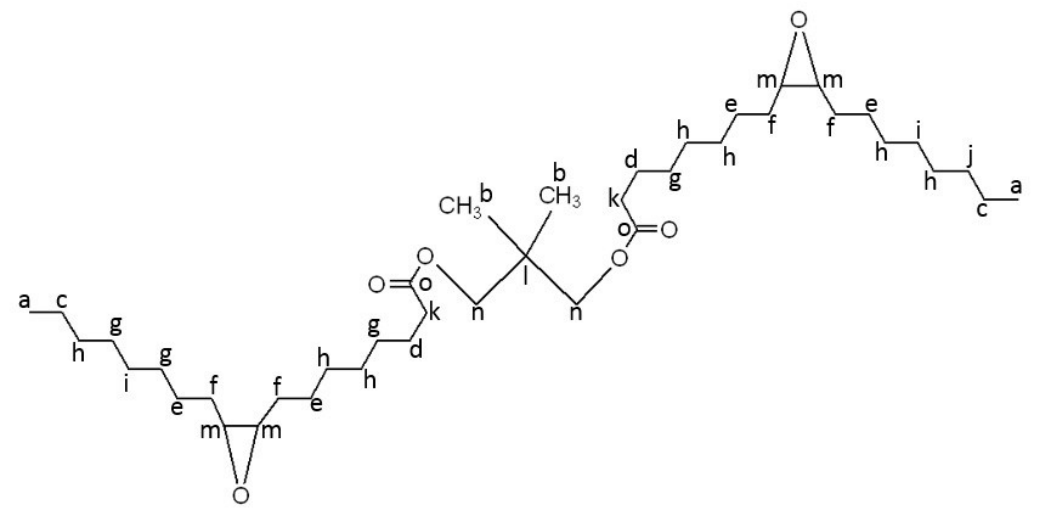

Figure 10. Structure representing signals on ${ }^{1} \mathrm{H}$ NMR spectra

The oxidative stability measures oil resistance towards oxidation. It is important as it reflects the shelf life of the oil [10]. The oxidative stability of ENPGDO has been increased from $177^{\circ} \mathrm{C}$ to $197^{\circ} \mathrm{C}$. Oxidative stability increased as the number of hydroxyl group decreased by forming free radicals. This have resulted in oxidative degradation [11]. The absence of double bond in the product have led to better oxidative stability. The flash point of epoxide is 205 ${ }^{\circ} \mathrm{C}$, which is significantly high to ensure safety during use. The ENPGDO possess a pour point of $-18^{\circ} \mathrm{C}$, which is higher than NPGDO which is $-44^{\circ} \mathrm{C}$. The pour point is a very important low temperature flow property where it indicates the lowest temperature at which the sample can be poured from a tilted jar [12]. The pour point tends to improve with the attachement of ester. The presence of this large branching group in the middle or end of the chain will have a steric hindrance effect, hence inhibit the formation of crystals [11]. The viscosity index of the epoxidized NPG dioleate is 218. The viscocity index increased as the molecular weight of product increased [13]. Through epoxidation, the oxidative stability and flash point have been improved compared to NPGDO. The viscocity index and pour point properties had decreased compared to NPGDO. These properties can be further improved by chemical modification of ENPGDO which acts as a biolubricant intermediate. The oxirane ring provides the site for further modification to obtain better properties.

\section{Conclusion}

The ENPGDO was succesully produced in high yield which was $83 \%$ with high percentage of OOC (4.3\%). The RCO of epoxide was also high, that was $97 \%$. The optimized condition for epoxidation process was at $40{ }^{\circ} \mathrm{C}$ for 3 hours, and the ratio of NPG dioleate to formic acid to hydrogen peroxide was 1:3:4. The oxidative stability of epoxide increased to $197^{\circ} \mathrm{C}$. The ENPGDO has $-18^{\circ} \mathrm{C}$ of pour point and $205^{\circ} \mathrm{C}$ of flash point. The viscosity index of the epoxide was achieved as 218 . The physicochemical properties of epoxide can be further modified through ring opening and other processes for better properties.

\section{Acknowledgement}

Authors thanked Universiti Kebangsaan Malaysia for providing the fund IP-2014-070, FRGS/2/2014/ST01/UKM/01/2 and all the staff from the Faculty of Science and Technology, Universiti Kebangsaan Malaysia for giving full support in completing this research.

\section{References}

1. Bart, J. C. J., Cavallaro, S. and Gucciardi, E. (2013). Biolubricants: Science and Technology. UK: Woodhead Publiching Limited.

2. Bilal, S., Mohammed-Dabo, I. A., Nuhu, M., Kasim, S. A., Almustapha, I. H. and Yamusa, Y. A. (2013). Production of biolubricant from Jatropha Curcas seed oil. Journal of Chemical Engineering and Materials Science, 4(6): $72-79$.

3. Fong, M. N. F. and Salimon, J. (2012). Epoxidation of palm kernel oil fatty acids. Journal of Science and Technology, 4(2): 87 - 98. 
4. Petrovic, Z., Zhang, W., Javni, I. and Guo, X. A. (2003). Polymer concrete containing vegetable oil- based polyurethanes and method for their preparation. US Patent 090016.

5. Ravindra, D. K., Priya, S. D., Sujay, U. M. and Pramod, P. M. (2013). Epoxidation of mustard oil and ring opening with 2- ethylhexanol for biolubricant with enhanced thermo- oxidative and cold flow characteristics. Industrial Crops and Products, 49: 586 - 592.

6. Meyer, P. P., Techaphattana, N., Manundawee, S., Sangkeaw, S., Junlakan, W. and Tongurai, C. (2008). Epoxidation of soybean oil and jatropha oil. Thammasat Internasional Journal Science Technology, 13: 1 - 5.

7. Gryglewicz, S., Piechocki, W. and Gryglewicz, G. (2003). Preparation of polyol esters based on vegetable and animal fats. Bioresource Technology, 87: 35 - 39.

8. Xuedong, W., Xingang, Z., Shengong, Y., Haigang, C. and Dapu, W. (2000). The study of epoxidized rapseed oil used as a potential biodegradable lubricant. Journal of the American Oil Chemists Society, 77(5): 561 - 563.

9. Rafiee- Moghaddam, R., Salimon, J., Jelas Haron, M. D., Jahangirian, H., Shah Ismail, M. H., Hosseini, S. and Rezayi, M. (2014). Lipase epoxidation optimizing of jatropha curcas oil using perlauric acid. Digest Journal of Nanomaterials and Biostructures, 9(3): 1159 - 1169.

10. Salimon, J., Bashar, M. A., Rahimi, M. Y. and Nadia, S. (2014). Synthesis, reactivity and application studies for different biolubricants. Chemistry Central Journal, 8:16 - 27.

11. Nadia, S., Salimon, J., Emad, Y. and Bashar, M. A. (2013). Biolubricant basestock from chemicaly modified plant oils: Ricinoleic acid based- tetraesters. Chemistry Central Journal, 7: 128 - 141.

12. Salimon, J., Nadia, S. and Emad, Y. (2012). Improvement of pour point and stability of synthetic ester basestocks for biolubricant applications. Arabian Journal of Chemistry, 5: $193-200$.

13. Salimon, J., Nadia, S. and Bashar, M. A. (2011). Improvement of physicochemical characteristic of monoepoxide linoleic acid ring opening for biolubricant base oil. Journal of Biomedicine and Biotechnology, 2011: $1-8$. 